J. Perinat. Med. $8(1980) 158$

\section{Continuous fetal pH monitoring and neonatal Apgar score}

Dept. of Obstetrics and Gynaecology, YA, Rigshospitalet, University of Copenhagen, Denmark

During the last 10-15 years continuous monitoring of fetal heart rate/uterine contractions and discontinuous fetal blood sampling (FBS) with $\mathrm{pH}$ estimation have been applied in order to evaluate the condition of the fetus.

During the last 2-3 years continuous fetal scalp tissue $\mathrm{pH}$ measuring during labour has been investigated $[5,6]$. The aim of this study was to evaluate the validity of continuous scalp tissue $\mathrm{pH}$ monitoring in predicting neonatal Apgar score.

\section{Material and method}

From September 1977 through February 1979, 152 patients were monitored during labour with a pH electrode (Kontron-Roche ${ }^{\circledR}$ ) [6].

The last tissue $\mathrm{pH}$ value preceding delivery has been estimated as follows: if the $\mathrm{pH}$ electrode is functioning until delivery of the fetal head, the $\mathrm{pH}$ value just before this moment is considered "the $\mathrm{pH}$ value at delivery". If the electrode is not working during the last $0-10$ minutes of labour, the $\mathrm{pH}$ value "at delivery" is estimated by extrapolation of the tracings, because this value correlates very well with the umbilical artery $\mathrm{pH}$ (see below). If the electrode stops working more than 10 minutes prior to delivery, the tracing has not been considered successful and is not included in the present investigation. If the tissue $\mathrm{pH}$ is equal to or less than 7.20 it is considered pathological.

APGAR scores of 9 or 10 one minute after delivery have been considered normal, whereas APGAR

\section{Curriculum vitae}

TOM WEBER was born and trained in Denmark. Since 1976 he has been working as a research fellow at the department of obstetrics and gynaecology (YA), Rigshospitalet, University of Copenhagen. The perinatal research has been in the area of fetal monitoring by $\mathrm{pH}$ electrodes and transcutaneous $\mathrm{pO}_{2}$ electrodes.

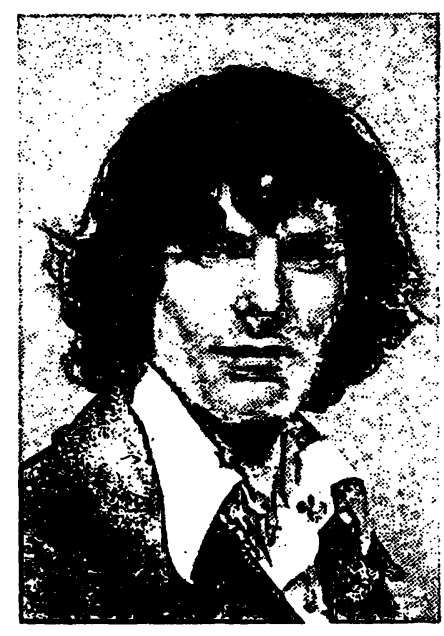

scores of less than or equal to 8 one minute after delivery have been considered pathological (see discussion).

CTG leading to obstetrical operations have been considered pathological, whereas the CTG's not causing the obstetrical staff to interfere have been considered normal.

As a rule cardiotocographic patterns leading to obstetrical intervention consisted of one or more of the following patterns: late decelerations, severe variable decelerations, and acute bradycardia. A decreased variability was considered pathological only if found together with severe tachycardia or any of the above mentioned pathological patterns. As the allowed duration of a pathological CTG pattern before obstetrical operation had to be carried out was not fixed, this decision was made by the obstetrician in charge of the patient. 
All CTG recordings were also seen by a senior obstetrician who was from another hospital and who did not know the outcome of the delivery. He also divided the CTG's into two groups: a pathological one in which operative intervention was needed, and a group in which no such operation seemed necessary.

The sensitivity (i. e. the proportion of "low APGAR" children found by the described method) and the specificity (i. e. the proportion of high APGAR children found by the method) have been calculated for tissue $\mathrm{pH}$ monitoring and CTG monitoring.

The patients were also grouped according to the CTG and the tissue $\mathrm{pH}$ "at delivery" versus the APGAR score, the above mentioned limits for CTG, $\mathrm{pH}$, and APGAR score being used.
The obstetrical management of the patients has not been influenced by the tissue $\mathrm{pH}$ value, which was not known to the obstetrician in charge of the patient.

\section{Results}

Table I illustrates the quality of the recordings obtained and the APGAR scores of the neonates one and five minutes after delivery, the mean tissue $\mathrm{pH}$ "at delivery" being compared to the APGAR scores one minute after delivery. Furthermore, the material is divided into two groups according to the umbilical artery $\mathrm{pH}$ at delivery $(\mathrm{pH} \leqslant 7.20$ or $>7.20$ ).

Eighty-one recordings allowed a comparison between the fetal scalp tissue $\mathrm{pH}$ at delivery and the neonatal APGAR score one minute after delivery (Tab. I).

Tab. I. Quality of pH recordings, distribution of APGAR scores one and five minutes after delivery, and distribution of umbilical artery $\mathrm{pH}$ at delivery.

\begin{tabular}{|c|c|c|c|c|c|c|}
\hline Quality of recordings* & & & & & No & Per cent \\
\hline $\begin{array}{l}\text { Acceptable } \\
\text { Not acceptable }\end{array}$ & & & & & $\begin{array}{l}81 \\
71\end{array}$ & $\begin{array}{l}53 \\
47\end{array}$ \\
\hline $\begin{array}{l}\text { APGAR score } \\
\text { (one minute after delivery) }\end{array}$ & No & $(\S)$ & Per cent & $(\S)$ & $\begin{array}{l}\text { Tissue pH } \\
\text { "at delive } \\
\text { (mean, }\end{array}$ & $\begin{array}{l}\text { I } \\
\text { SEM) }\end{array}$ \\
\hline $\begin{array}{l}10 \\
9 \\
8 \\
7 \\
6 \\
5 \\
0-4\end{array}$ & $\begin{array}{r}58 \\
55 \\
21 \\
11 \\
1 \\
1 \\
5\end{array}$ & $\begin{array}{r}(32) \\
(29) \\
(14) \\
(4) \\
(0) \\
(0) \\
(2)\end{array}$ & $\begin{array}{r}38 \\
36 \\
14 \\
7 \\
1 \\
1 \\
3\end{array}$ & $\begin{array}{r}(40) \\
(36) \\
(18) \\
(5) \\
(0) \\
(0) \\
(2)\end{array}$ & $\begin{array}{l}\mathbf{( 7 . 2 5 ,} \\
\mathbf{( 7 . 2 6 ,} \\
(7.21, \\
(7.15, \\
- \\
\overline{(7.18} \&\end{array}$ & $\begin{array}{l}0.01 \text { ) } \\
0.01 \text { ) } \\
0.03 \text { ) } \\
0.03 \text { ) } \\
- \\
\overline{7.31)}\end{array}$ \\
\hline $\begin{array}{l}\text { APGAR score } \\
\text { (five minutes after delivery) }\end{array}$ & No & (§) & Per cent & (§) & & \\
\hline $\begin{array}{l}10 \\
9 \\
8 \\
0-7\end{array}$ & $\begin{array}{r}137 \\
11 \\
3 \\
1\end{array}$ & $\begin{array}{r}(75) \\
(3) \\
(3) \\
(0)\end{array}$ & $\begin{array}{r}90 \\
7 \\
2 \\
1\end{array}$ & $\begin{array}{r}(93) \\
(4) \\
(4) \\
(0)\end{array}$ & & \\
\hline $\begin{array}{l}\text { Umbilical artery } \mathrm{pH} \\
\text { (at delivery) }\end{array}$ & No & $(\S)$ & Per cent & (§) & & \\
\hline $\begin{array}{l}>7.20 \\
\leqslant 7.20\end{array}$ & $\begin{array}{r}100 \\
42\end{array}$ & $\begin{array}{l}(56) \\
(23)\end{array}$ & $\begin{array}{l}70 \\
30\end{array}$ & $\begin{array}{l}(71) \\
(29)\end{array}$ & & \\
\hline
\end{tabular}

* Acceptable (for correlation to neonatal APGAR score): stable pH values until at least 10 minutes prior to delivery. Not acceptable (for correlation to neonatal APGAR score): no satisfactory recording during the last part of delivery (more than 10 minutes).

$\S$ No and per cent in brackets refer to the infants with acceptable $\mathrm{pH}$ recordings. 
A positive correlation $(\mathrm{r}=0.83, \mathrm{p}<0.01)$ was found between the umbilical artery $\mathrm{pH}$ and the $\mathrm{pH}$ value "at delivery" in cases where extrapolation during the last $0-10$ minutes of labour was necessary (results not shown).

Tab. II shows correlations between tissue $\mathrm{pH}$ and APGAR scores. The sensitivity of tissue $\mathrm{pH}$ is 67 per cent, the specificity is 73 per cent.

The evaluation of the CTG recordings of all the patients made by the staff of the obstetrical department resulted in either obstetrical operation or no such operation. The sensitivity of CTG in detecting children who would have low APGAR scores was 42 per cent (Tab. II). This means that 58 per cent of the neonates having APGAR scores of 8 or less one minute after delivery were not detected by CTG. The specificity of the method was 81 per cent (Tab. II). This means that only 19 per cent of the neonates delivered by obstetrical operation because of pathological CTG had high APGAR scores (9 or 10) one minute after delivery. The evaluation based upon the senior obstetrician who did not know the outcome or the course of labour showed almost identical results, namely a sensitivity of 42 per cent and a specificity of 75 per cent.

There was no statistical difference $(p>0.10$, Fourfold Table Test) between the sensitivity and the specificity of tissue $\mathrm{pH}$ measurements and CTG monitoring.

Table III shows that in case of a normal $\mathrm{pH}$ and a pathological CTG no neonates obtained APGAR scores of less than 8. Only one infant obtained an APGAR score of 8 with a normal $\mathrm{pH}$ and a pathological CTG. This infant was delivered by outlet forceps because of severe variable decelerations and had an APGAR score of 10 five minutes after delivery (tissue $\mathrm{pH} 7.30$, umbilical artery $\mathrm{pH} 7.33$ at delivery). The other six neonates with a normal tissue $\mathrm{pH}$ but an APGAR score of 0-8 were considered "normal" by CTG as well. Six neonates with APGAR scores of 9-10 were delivered by obstetrical operations (one outlet forceps, five "early" episiotomies) because of a "pathological" CTG but with a normal tissue $\mathrm{pH}$. So, although there is no statistical difference between the sensitivity and specificity of tissue $\mathrm{pH}$ and CTG, only one child (APGAR 8) would not have been "saved"
Tab. II. Sensitivity and specificity of tissue $\mathrm{pH}$ monitoring and of cardiography (CTG) in predicting neonatalAPGAR scores one minute after delivery.

\begin{tabular}{lll}
\hline & Tissue & Tissue \\
& $\mathrm{pH} \leqslant 7.20$ & $\mathrm{pH} \geqslant 7.21$ \\
\hline APGAR $\leqslant 8$ (No of patients) & 14 & 7 \\
APGAR $\geqslant 9$ (No of patients) & 16 & 44
\end{tabular}

Sensitivity $14 / 21=67$ per cent; specificity $44 / 60=73$ per cent.

Pathological
CTG
(see text)

APGAR $\leqslant 8$ (No of patients) 15 21 APGAR $\geqslant 9$ (No of patients) 22 94

Sensitivity $15 / 36=42$ per cent; specificity $94 / 116=81$ percent.

by using tissue $\mathrm{pH}$ monitoring alone. Six unnecessary obstetrical operations were carried out because of suspected pathological CTG's. This could have been omitted by continuous $\mathrm{pH}$ measurements.

\section{Discussion}

The condition of the neonates in this material is estimated by the APGAR score one and five minutes after delivery. Other scoring systems have been proposed but have been given up shortly after their introduction. Although the APGAR scoring is not a very precise indicator of the overall condition of the neonate and of the prognosis of later development of the infant [3], no better way has yet been proven effective.

Unfortunately, the $\mathrm{pH}$ of the fetus (during labor or in the umbilical arterial blood after delivery) has not been compared to the development of the infant in any major material, the $\mathrm{pH}$ possibly being of higher prognostic value than the APGAR score. At present, the only way of evaluating different methods of fetal monitoring is to let the monitoring system discriminate between fetuses having low and high APGAR scores.

In a study based on the previous literature on the subject WEBER [7] has compared the sensitivity and specificity of $\mathrm{pH}$ measurements after fetal blood sampling with cardiotocography. The sensi- 
tivity of CTG was 50-80 per cent, but only after evaluation of the CTG by a few or one expert(s) or by a computer - after delivery had taken place. The specificity of CTG was 50-90 per cent in the same study. The sensitivity of FBS-pH was 50-70 per cent and the specificity was $80-90$ per cent. In the above mentioned study the APGAR score limit was between 6 and 7, while the limit was defined as being between 8 and 9 in the present study. An APGAR limit between 8 and 9 is high, but very few of the neonates in the present mateial had low APGAR scores (Tab. I: Only 2 and 0 per cent of the infants with acceptable recordings had APGAR scores of less than 7 one and five minutes after delivery, respectively). As the ultimate goal must be to deliver healthy infants, we have chosen this high limit. A distinction between children with APGAR scores of 9-10 and 0-8 also seems reasonable as mean tissue $\mathrm{pH}$ "at delivery" declines from 7.26 to 7.21 when the APGAR score declines from 9 to 8 (Tab. I).

At present, the discussion as to the value of the APGAR score one minute after delivery versus five minutes after delivery in predicting future prognosis of the infant is still going on. Two recent studies $[1,4]$ indicate that the APGAR score one minute after delivery correlates better to later neurological status (at one year of age) than does the APGAR score five minutes after delivery. Earlier reports [2,3] find however that the APGAR score after five minutes is better in predicting later development of the infant. In the present material, the small number of children with low APGAR scores five minutes after delivery (Tab. I) made it impossible to calculate sensitivity and specificity of the APGAR scores both one and five minutes after delivery.

As it should be expected to be more difficult to discriminate between APGAR scores of 9-10 versus $0-8$ than to discriminate between scores of $7-10$ versus $0-6$, and as the CTG recordings in this study were not estimated by experts or computers, the sensitivity of CTG ( 42 per cent) found in this study is not surprisingly low.

\section{Conclusion}

This study shows that 67 per cent of infants with an APGAR score of 8 or less can be detected by continuous $\mathrm{pH}$ measurements using 7.20 as the limit. Reading the $\mathrm{pH}$ meter digits is easier than interpretation of the CTG. The sensitivity of tissue $\mathrm{pH}$ measurements of 0.67 is as good as the sensitivity of FBS-pH, although tissue $\mathrm{pH}$ monitoring in the present study should also "find" neonates with APGAR scores of 7 and 8. This is done without lowering the specificity of the method ( 73 per cent), which is almost as good as the specificity of earlier studies (80-90 per cent) [7].

The use of tissue $\mathrm{pH}$ monitoring instead of CTG would not have raised the number of obstetrical operations. If CTG and tissue $\mathrm{pH}$ are combined better results would be expected than using one or the other (see Tab. III), but this cannot be evaluated before the CTG and the tissue $\mathrm{pH}$ are both used in the management of labor.

Tab. III also shows that if action is not taken when the CTG is normal and the tissue $\mathrm{pH}$ is

Tab. III. The relationship between CTG + tissue $\mathrm{pH}$ and neonatal APGAR score one minute after delivery in the case with acceptable $\mathrm{pH}$ recordings (Definitions: see text).

\begin{tabular}{llllll}
\hline CTG: & $\begin{array}{l}\text { Patho- } \\
\text { logical }\end{array}$ & Normal & $\begin{array}{l}\text { Patho- } \\
\text { logical }\end{array}$ & Normal \\
& pH: & Normal & $\begin{array}{l}\text { Patho- } \\
\text { logical }\end{array}$ & $\begin{array}{l}\text { Patho- } \\
\text { logical }\end{array}$ & Normal \\
& & $(\mathrm{No})$ & (No) & (No) & (No) \\
\hline APGAR & $0-4^{*}$ & 0 & 0 & 1 & 1 \\
APGAR & $7 *$ & 0 & 2 & 1 & 1 \\
APGAR & $0-7 / 8-10$ & $0 / 7$ & $2 / 18$ & $2 / 8$ & $2 / 42$ \\
APGAR & 8 & 1 & 6 & 4 & 4 \\
APGAR & $0-8 / 9-10$ & $1 / 6$ & $8 / 12$ & $6 / 4$ & $6 / 38$
\end{tabular}

Sensitivity of pH (APGAR limit 7/8): 4/6 = 67 per cent Specificity of pH (APGAR limit 7/8): 49/75 $=65$ percent

Sensitivity of CTG (APGAR limit 7/8): 2/6 = 33 per cent Specificity of CTG (APGAR limit 7/8: 60/75=80percent

* Of the six children with APGAR scores of 0-7, four had an uncomplicated neonatal period (APGAR scores of $4 / 10,4 / 10,7 / 8,7 / 8$ one/five minutes after delivery); one infant was observed for cyanosis but was found to be normal by the neonatologists (APGAR score 7/9 one/five minutes after delivery); and the last neonate (APGAR score $7 / 8$ one/five minutes after delivery) had fetal tachycardia (about 190-210) detected three weeks before delivery and was born with cardiac incompensation; third trimester intrauterine infection was suspected but never proven and the neonate died 9 days old from cardiac incompensation (no other explanations were found at the autopsy). 
pathological $8 / 21$ infants will be delivered with APGAR scores of 0-8. CTG therefore is not always enough to detect all cases that could benefit from $\mathrm{pH}$ monitoring. In order to achieve the best possible results in the future all fetal monitoring should include monitoring of fetal tissue $\mathrm{pH}$. However, this requires the availability of a better electrode.

As extrapolation of the $\mathrm{pH}$ curve (10-0 minutes prior to delivery) made it possible to predict the umbilical artery $\mathrm{pH}(\mathrm{r}=0.83, \mathrm{p}<0.01)$ it should be possible to predict the $\mathrm{pH}$ for at least $10 \mathrm{mi}$ nutes and therefore to take, action before the fetus reaches a critical pH level. Also, spontaneous delivery can continue until at least 10 minutes before the critical $\mathrm{pH}$ level is reached, thus saving some obstetrical operations.

As the $\mathrm{pH}$ electrode is still difficult to apply to the fetus and as there are still too many cases of unsuccessful $\mathrm{pH}$ recordings, tissue $\mathrm{pH}$ monitoring should only be used for investigational purposes at the present time.

\section{Summary}

Results of continuous fetal tissue $\mathrm{pH}$ monitoring were compared to neonatal APGAR scores one minute after delivery in 81 successful tissue $\mathrm{pH}$ recordings. The sensitivity of the method (i.e. the ability of the method to find the low APGAR neonates) was 67 per cent using an APGAR score limit between 8 and 9 and a pH limit between 7.20 and 7.21. The specificity (i.e. the ability of the method to find the high APGAR neonates) was 73 per cent using the same limits.

Keywords: Continuous fetal pH monitoring, fetal heart rate monitoring, fetal scalp sampling, intrapartum management, neonatal APGAR score.

\section{Zusammenfassung}

Kontinuierliche pH-Messung beim Feten und APGARScore

In 81 Fällen wurde eine kontinuierliche pH-Messung im fetalen Gewebe vorgenommen und die Ergebnisse den APGAR-Score-Werten 1 Minute post partum gegenübergestellt. Um die Sensitivität unserer Methode (d.h., die Wahrscheinlichkeit, Kinder mit niedrigem APGARScore $\mathrm{zu}$ erfassen) $\mathrm{zu}$ prüfen, legten wir ein Intervall zwischen 8 und 9 hinsichtlich des APGAR-Scores und den Grenzbereich zwischen 7.20 und 7.21 hinsichtlich des $\mathrm{pH}$ 's zugrunde. Unter Benutzung dieser Intervalle betrug die Sensitivität $67 \%$. Die Spezifität der Methode (d.h. die Wahrscheinlichkeit, Kinder mit höheren APGAR-
The sensitivity and specificity of continuous $\mathrm{pH}$ monitoring was equal to or better than the sensitivity and specificity of cardiotocography and discontinuous $\mathrm{pH}$ measurements on fetal scalp blood using APGAR score limits between 6 and 7 .

It is concluded that all fetal monitoring should include monitoring of the fetal $\mathrm{pH}$ when a $\mathrm{pH}$ electrode which can be used as a routine instrument has been developed. Unfortunately, such an electrode has not been developed yet.

Schlüsselwörter: Fetale Kopfblutanalyse, Geburtsleitung, kontinuierliche fetale pH-Überwachung, neonataler APGARScore, Überwachung der fetalen Herzfrequenz.

\section{Resumé}

Monitorage continu du $\mathrm{pH}$ foetal et score néonatal D'APGAR

Les résultats du monitorage continu du $\mathrm{pH}$ tissulaire foetal ont été comparés aux scores néonataux D'APGAR
Werten $\mathrm{zu}$ erfassen), lag bei $73 \%$ unter Benutzung derselben Grenzwerte.

Die Sensitivität und Spezifität einer kontinuierlichen pH-Überwachung war vergleichbar, wenn nicht sogar besser als die Sensitivität und Spezifität von Kardiotokographie und diskontinuierlichen pH-Messungen im fetalen Kopfblut, wobei APGAR-Grenzwerte zwischen 6 und 7 zugrunde lagen.

Die fetale Überwachung sollte daher auch die kontinuierliche pH-Messung einschließen. Das setzt allerdings voraus, daß eine pH-Elektrode, die als Routineinstrument verwendbar ist, entwickelt wird. Leider können wir zur Zeit auf eine solche Elektrode noch nicht zurückgreifen. à une minute après l'expulsion au cours de 81 enregistrements réussis de pH tissulaire, La fiabilité de la méthode (c'est-à-dire sa capacité de détecter les nouveau-nés au score D'APGAR bas) a été de $67 \%$ en utilisant des limites 
de score D'APGAR allant de 8 à 9 ainsi que de $\mathrm{pH}$ comprises entre 7,20 et 7,21. La spécificité de la méthode (c'est-à-dire sa capacité de détecter les nouveau-nés au score D'APGAR élevé) était de $73 \%$ en utilisant les mêmes valeurs limites.

La fiabilité et la spécificité du monitorage continu du $\mathrm{pH}$ étaient égales ou meilleures par rapport à celles de la cardiotocographie et des mesures de $\mathrm{pH}$ discontinues sur le scalp foetal en utilisant des limites de score D'APGAR comprises entre 6 et 7 .

Il en résulte que tout monitorage foetal doit comprendre celui du $\mathrm{pH}$ foetal lorsque l'électrode de $\mathrm{pH}$ aura été développée en tant qu'instrument de routine. Malheureusement ce n'est point encore le cas.

Mots-clés: Conduite à tenir intrapartum, échantillons au scalp foetal, monitorage continu du pH foetal, monitorage de la fréquence cardiaque foetale, score néonatal D'APGAR.

Acknowledgement: This work was supported by the "DAGMAR MARSHAL Fund".

\section{Bibliography}

[1] ANDRE, M., P. VERT, C. DEBRUILLE: Diagnostic et évolution de la soufrance cérébrale chéz les nouveau-nés ayant présénte des signes dhypoxie foetale. Arch. Fr. Pediatr. 35 (1978), 23

[2] APGAR, V.: The newborn (APGAR) scoring system. Pediatr. Clin. North Am. 13 (1966) 645

[3] DRAGE, J. S., H. BERENDES: APGAR score and outcome of the newborn. Pediatr. Clin. North Am. 13 (1966) 635

[4] PAINTER, M. J., R. DEPP, P. D. O'DONOGHUE: Fetal heart rate patterns and development in the first year of life. Amer. J. Obstet. Gynec. 132 (1978) 271
[5] STURBOIS, G., S. UZAN, D.ROTTEN,G.BREART, C. SUREAU: Continuous subcutaneous $\mathrm{pH}$ measurement in human fetuses. Amer. J. Obstet. Gynec. 128 (1977) 901

[6] WEBER, T., S. HAHN-PEDERSEN, J. E. BOCK: Continuous fetal tissue $\mathrm{pH}$ recordings during labor. Brit. J. Obstet. Gynaec. 85 (1978) 770

[7] WEBER, T.: The validity of discontinuous $\mathrm{pH}-$ measurements on fetal blood and of cardiotocography in predicting neonatal APGAR score. Dan. Med. Bull. 26 (1979) 186

Received September 11, 1979. Revised January 28, 1980. Accepted February 12, 1980.
Dr. Tom Weber

Skraaplanet 22

DK-2750 Ballerup

Denmark 